\title{
Provision and Implementation of the Faculty Manual: Its Relation to Teachers Affective Commitment and Job Satisfaction
}

\author{
Roel D. Juevesa
}

\begin{abstract}
Faculty manual guides the teachers about their jobs and gives them the general information about the school policies. The proper implementation of its provision can make teachers highly committed and satisfied in the workplace. This study examined the relationship between the provision and implementation of the faculty manual and teachers' affective commitment and job satisfaction. The descriptive survey and correlational research design was used employing quantitative method. The data were gathered through the survey questionnaire and administered to the sixty (60) respondents from teaching personnel of Ramon Magsaysay Memorial Colleges (RMMC). The data gathered were analyzed through percentage, weighted mean and pearson correlation. The results of the data analysis showed that the teachers agreed that the faculty manual was complete in terms of provision but needs consistency in the manner of implementation. Moreover, the findings of the study revealed that the provision and implementation of the faculty manual has something to do with teacher's affective commitment and job satisfaction in the organization. Thus, it showed that there is a significant relationship between the provision and implementation of the faculty manual and teacher's affective commitment. Furthermore, it showed that there is a significant relationship between provision and implementation of the faculty manual and teacher's job satisfaction. Therefore, the two (2) null hypotheses of the study are rejected. Given the overall results, the study recommends that enhancement and consistent implementation of faculty manual are needed to further improve the teacher's affective commitment and job satisfaction.

Keywords: Employee Commitment, Faculty Manual, Job Satisfaction, Teacher
\end{abstract}

\section{INTRODUCTION}

A manual or handbook is a comprehensive and step by step guide that serves as a reference book that prescribes the movement of an individual (Payne \& Majale, 2004) [21]. It details what is given and what is required, explains how to put the presented information into practice, and instructs how to solve problem as they occur (Mital, et, al, 1997) [20]. Every organization has its own manual to properly direct them on how to run the organization smoothly. It comes in a different form depending on the institutions needing them. It can be

Revised Manuscript Received on August 13, 2020.

* Correspondence Author

Roel D. Juevesa*, Business College, Ramon Magsaysay Memorial Colleges (RMMC), General Santos City, Philippines. E-mail: roel.juevesa@yahoo.com

(C) The Authors. Published by Blue Eyes Intelligence Engineering and Sciences Publication (BEIESP). This is an open access article under the CC BY-NC-ND license (http://creativecommons.org/licenses/by-nc-nd/4.0/) employee manual, student manual and most importantly faculty manual for an educational institution (Allison \& Kaye, 2011) [1].

A faculty manual is a guide to faculty and is design to present the general information about the school (Steinert, et. al, 2006) [27]. It also discusses some important policies and practices that will apply to faculty. It is also meant to inform and serve other members of the community. Usually it is being received by employee before employing in the institution for him to be informed of the possible concern that he might be facing in the future (Barkley \& Major, 2020) [6].

In the teaching profession, faculty manual needs to be understood by every employee (Darling-Hammond \& Mclaughlin, 1995) [7]. If employees are well-aware of the manual contents like the statement of the policies, the practices, the benefits and the like, he is guided well on how to behave and avail himself of the needed legal protection in the future. However, as time goes by manual becomes obsolete and needs to be revisited too. There might be some policies and practices which need updating for the common benefit of the employee and employer (Edgar \& Geare, 2005) [9]. In fact, a well-written and implemented manual has something to do with teacher's commitment and satisfaction (Eaton, 2003) [8].

The Ramon Magsaysay Memorial Colleges (RMMC) is a private non-sectarian school, a higher educational institution (HEI) in General Santos City, is been on its sixty (60) years in the industry. As of May 31, 2019, it has two hundred five (205) employees where one hundred thirteen (113) of it is a teacher. Each of them had their own copy of faculty manual that serves them as a guide. However, the manual itself is subject to revision depending if there is an updates needed to be included which might not been consider before.

Thus, this study was conducted to examine the provision and the implementation of the existing faculty manual of RMMC and its relation for to teachers' affective commitment and job satisfaction.

\section{STATEMENT OF THE PROBLEM}

This study aimed to enhance the faculty manual of Ramon Magsaysay Memorial Colleges (RMMC) in order to improve teachers' affective commitment and job satisfaction.

Specifically, it aimed to answer the following questions:

1. What is the level of perception of the respondents to the provision and implementation of the existing faculty manual in terms of the following:

Published By:

Blue Eyes Intelligence Engineering \& Sciences Publication

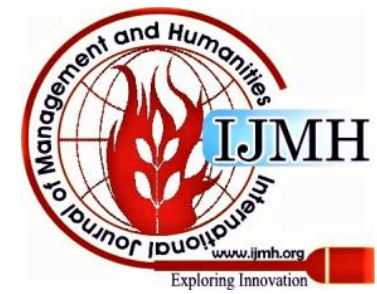


a. Employment Policies;

b. Faculty Qualifications;

c. Faculty Ranking; and

d. Salary and Benefits?

2. What are the strengths and weaknesses (SW) on the existing faculty manual?

3. What is the level of affective commitment of the respondents?

4. What is the level of job satisfaction of the respondents?

5. Is there a significant relationship between the provision and implementation of the faculty manual and affective commitment?

6. Is there a significant relationship between the provision and implementation of the faculty manual and job satisfaction?

7. What enhancement shall be considered to the faculty manual based on the results of the study?

\section{CONCEPTUAL FRAMEWORK}

A manual serves as a guide to all employees in the organization (Lindsey, et. al, 2019) [18]. It is very important for them to be aware of the things they need to know about their employment. It discusses about the status and benefits of their employment and even the manner on how they behave in the organization (Koziel, 2009) [15].

A faculty manual plays a vital role in every educational institution in the country. It's not only because of accreditation requirements, but it guides the administration and teachers about the issues they need to give attention (Pierangeli, 2006) [22]. This manual is enforceable, valid and binding contract as signed by the authority of the school. It underwent proper deliberation (Lettner-Rust, 2018) [16] and discussion with all the people at stakes where its implementation might affect employee's commitment and job satisfaction. Commitment can be defined in many ways (Arora, Nuseir, \& Nusair, 2012) [4]. However, Sani (2013) [24] defined organizational commitment as the desire and the willingness of an employee to contribute positively on the organizational success. Meanwhile, Ellenbecker \& Cushman (2012) [10] considered the various reasons of organizational commitment and they defined it as the reason that drive employee's attachment to an organization. Some researches include moral attachment, emotional commitment and obligation (Balassiano \& Salles, 2012; Ellenbecker \& Cushman, 2012) [5, 10]. However, Meyer \& Allen (1997) [19] stated that employee's commitment comes into three contexts; the affective commitment, normative commitment and continuance commitment. Affective commitment stated that employees may commit to the organization they are employed because they are satisfied and they feel the sense of belongingness (Kimura, 2023; Jussila,Byrne, \& Touminen, 2012) [14,13]. Affective commitment is the level to which employees feel to be linked emotionally, identified, and involved with the organization and employees want to remain at the organization (Balassiano \& Salles, 2012; Juevesa et. al, 2020) [5,12]. It refers to the emotional attachment the employees had to their employing organization (Leroy et al., 2012) [17]. On the other hand, Job satisfaction refers to the attituted and feelings people have about their work (Armstrong, 2006) [3]. Ellickson \& Logsdon (2002) [11] support this view by defining the term job satisfaction as the extent to which employees like their work. Also Spector
(1997) [25] defined this as how people feel about their jobs and different aspects of their jobs. Similarly, Statt (2004) [26] said that job satisfaction is an extent to which a worker is content with the rewards he or she gets out of his or her jobs (Rasiq, et.al, 2019) [23]. In the context of the study, this study is about assessing the relevance of the provision and implementation of existing faculty manual of RMMC and its relation on how the employees commit and satisfy with their jobs. The affective commitment had been anchored from Meyer \& Allen (1997) [19], while the indicators of job satisfaction had been adapted from Al-dalahmeh, et. al (2018) [2]. Figure 1 shows the conceptual framework of the study based on the above stated theoretical anchors.

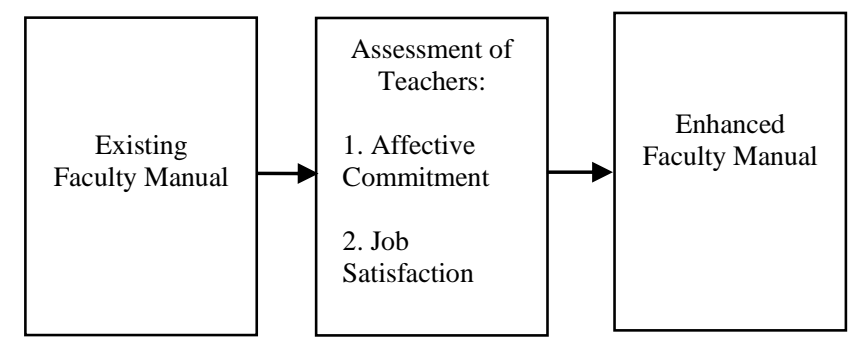

Figure 1. Conceptual Framework of the Study

\section{METHODOLOGY}

\section{A. Research Design}

The study used descriptive survey and correlational method of research, which includes gathering, classification, and presentation of data. This research methodology is appropriate in assessing the relevance and enhancing the existing faculty manual of RMMC to further improve employee's affective commitment and job satisfaction. They are valuable in providing facts on which scientific judgment may be based.

\section{B. Research Locale}

The study was conducted at Ramon Magsaysay Memorial Colleges (RMMC) in General Santos City. RMMC is a private and non-sectarian higher educational institution (HEI). It exists in the industry for sixty (60) years and offers undergraduate programs and master's degree programs with an average of seven thousand $(7,000)$ students every semester.

\section{Respondents of the Study}

In assessing the relevance of the existing faculty manual, the respondents of the study are the sixty (60) teaching personnel of RMMC. They were identified as respondents because they are the individual who directly involved in teaching and they are the subject of the study in determining the affective commitment and job satisfaction.

\section{Research Instruments}

In view of the fact that this study is a descriptive survey in nature, the main instrument used in gathering the data is Survey Questionnaire (SQ). The questionnaire for the provision and implementation of the faculty manual was validated through a reliability test using Chronbach alpha with .964 reliability coefficient.

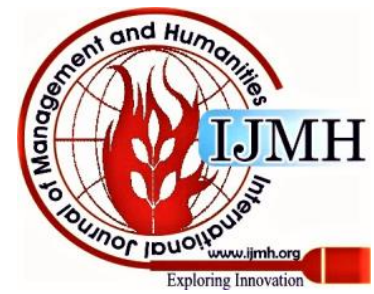


For the affective commitment, it was anchored from Meyer \& Allen (1997) [19]. Lastly, the job satisfaction was adapted from Al-dalahmen,et.al (2018) [2]. In answering the questionnaires, the five-point Likert Scale was used with the following responses: 5=Strongly Agree; 4=Agree; 3=Neutral; 2=Disagree; 1=Strongly Disagree.

\section{E. Data Analysis}

The data were gathered from each respondent was tallied, tabulated and subjected to the following statistical treatment; Percentage, it was used to identify the proportion of respondents answers among presented indicators; Weighted Mean, it was used to measure the central tendencies of the gathered data to further explain the level of perceptions in the provision and implementation of the faculty manual, the affective commitment, and job satisfaction; Correlation, it was used to measure the strength and direction of a linear association between two variables. This was used to determine the mean relationship of the provision and implementation of the faculty manual to employee commitment and job satisfaction.

\section{RESULT AND DISCUSSION}

\section{A. Assessment of Existing Faculty Manual and SW Analysis}

In terms of assessment, the indicators with a rating of 3.41 to 5.00 are considered as strengths while the indicators with a rating of 1.00 to 3.40 are considered as weaknesses.

In response to the first objective which is assessing the existing faculty manual. There are four (4) areas being considered employment policies, the faculty qualifications, faculty ranking, and salary and benefits.

\section{Employment Policies}

The table 1 shows the results on the survey conducted for existing faculty manual in terms of employment policies.

Table 1. Employment Policies

\begin{tabular}{|c|c|c|}
\hline INDICATORS & $\begin{array}{c}\text { WEIGHTED } \\
\text { MEAN }\end{array}$ & $\begin{array}{l}\text { INTERPRE } \\
\text { TATION }\end{array}$ \\
\hline $\begin{array}{l}\text { 1. The policies for hiring, transfer } \\
\text { and promotion, resignation, } \\
\text { code of conducts, and } \\
\text { retirement were clearly stated } \\
\text { in the manual }\end{array}$ & 4.42 & $\begin{array}{c}\text { Strongly } \\
\text { Agree }\end{array}$ \\
\hline $\begin{array}{l}\text { 2. The job induction program was } \\
\text { conducted before an employee } \\
\text { was deployed on their specific } \\
\text { program/department. }\end{array}$ & 4.33 & $\begin{array}{c}\text { Strongly } \\
\text { Agree }\end{array}$ \\
\hline $\begin{array}{l}\text { 3. The department policies for } \\
\text { teaching and academic } \\
\text { compliances were clearly } \\
\text { explained by the Head of the } \\
\text { Office before the actual } \\
\text { teaching job. }\end{array}$ & 4.00 & Agree \\
\hline $\begin{array}{l}\text { 4. The job description for } \\
\text { teaching job was available and } \\
\text { the contract was discussed } \\
\text { clearly to each employee. }\end{array}$ & 3.83 & Agree \\
\hline $\begin{array}{l}\text { 5. The implementations of the } \\
\text { employment policies were } \\
\text { consistent in the provision of } \\
\text { the manual. }\end{array}$ & 3.33 & Neutral \\
\hline Average Weighted Mean & 3.99 & Agree \\
\hline
\end{tabular}

The employment policies obtained an average weighted mean of 3.99 which is interpreted as agree. Data shows that the respondents perceive that in general the employment policies of the school are always put in place. Furthermore, its shows that the employment policies of the school are clearly stated in the provision of the manual where teachers are clearly guided and well-aware about it.

On the indicators presented, the indicator 1, "the policies for hiring, transfer and promotion, resignation, code of conducts, and retirement were clearly stated in the manual" got the highest rating of 4.42 and is interpreted as strongly agree. It reveals that the teachers are very highly agreed that the manual of the school provided well all the information needed about their employment. It further indicates the effectiveness of the administration in giving information to teachers about their employment policies upon entry through hiring and even up to exit through resignation or retirement.

However, the indicator 5, "the implementations of the employment policies were consistent in the provision of the manual" got the lowest rating of 3.33 which is being interpreted as neutral. This data implies that despite of the well-written employment policies, the respondents perceive that there is lack of implementation about the said policies. Moreover, there might be an inconsistencies observed by the respondents in terms of implementation that cause them to believe that there are instances that manual is not being followed. The rest of the indicators are rated as follows: indicator 2, "the job induction program was conducted before an employee was deployed on their specific program/department" got 4.33, strongly agree; indicator 3, "the department policies for teaching and academic compliances were clearly explained by the Head of the Office before the actual teaching job" got 4.00, moderately agree; and the indicator 3 "the job description for teaching job was available and the contract was discussed clearly to each employee", got 3.33, moderately agree.

\section{Faculty Qualifications}

The table 2 shows the results on the survey conducted for existing faculty manual in terms of faculty qualifications.

Table 2. Faculty Qualifications

\begin{tabular}{|c|c|c|}
\hline INDICATORS & $\begin{array}{c}\text { WEIGHTED } \\
\text { MEAN }\end{array}$ & $\begin{array}{c}\text { INTERPRE } \\
\text { TATION }\end{array}$ \\
\hline $\begin{array}{c}\text { 1. The masters' degree qualification is } \\
\text { a requisite for hiring teachers. }\end{array}$ & 3.52 & Agree \\
\hline $\begin{array}{c}\text { 2. The professional license is a } \\
\text { requirement in hiring for board } \\
\text { course program. }\end{array}$ & 3.48 & Neutral \\
\hline $\begin{array}{c}\text { 3. The teaching experience is required } \\
\text { for hiring. }\end{array}$ & 3.38 & Strongly \\
Agree
\end{tabular}

Published By:

Blue Eyes Intelligence Engineering \& Sciences Publication (C) Copyright: All rights reserved. 


\section{Provision and Implementation of the Faculty Manual: Its Relation to Teachers Affective Commitment and Job Satisfaction}

The general weighted mean of faculty qualifications is 3.72 which is interpreted as agree. The data implies that the school has the clear provision of hiring faculty on the bases on qualifications.

It also implies that this hiring as base on qualifications is consistently applied by the Human Resource Office.

Among the indicators, the indicator 4 , "the faculty is teaching subject largely in his/her major field, or for professional courses" got the highest rating of 4.21 which is interpreted as strongly agree. The data reveals that the respondents very highly agreed that they teach on the subjects of their particular expertise and this was implemented and practice by the school most of the time. This is evident as the school was accredited with level 3 status program.

On the other hand, the indicator 3, "the teaching experience is required for hiring", got the lowest rating of 3.38 which is interpreted as neutral. Data shows that teachers perceive that hiring experience do not guarantee that you will be hired in the school. The data further implies that teaching experience is an advantage but does not necessarily the bases of the Human Resource Office to employ teachers immediately. The rest of the indicators are rated as follows; indicator 1 "the masters' degree qualification is a requisite for hiring teachers" got 3.52, agree; indicator 2, "the professional license is a requirement in hiring for board course program" got 3.48, agree; and indicator 5, "vertical alignment of master's and doctorate degree are considered" got 4.00 , agree.

\section{Faculty Ranking}

Table 3 below shows the results of assessing the relevance of the existing faculty manual in terms of faculty ranking.

Table 3. Faculty Ranking

\begin{tabular}{|c|c|c|}
\hline INDICATORS & $\begin{array}{c}\text { WEIGHTED } \\
\text { MEAN }\end{array}$ & $\begin{array}{c}\text { INTERPRE } \\
\text { TATION }\end{array}$ \\
\hline $\begin{array}{c}\text { 1. The educational qualification is the } \\
\text { major bases in ranking the faculty. }\end{array}$ & 4.13 & Agree \\
\hline $\begin{array}{l}\text { 2. The points given in the ranking } \\
\text { parameters are justifiable and } \\
\text { reasonable. }\end{array}$ & 3.90 & Agree \\
\hline $\begin{array}{l}\text { 3. The performance evaluation is } \\
\text { included in the ranking } \\
\text { parameters. }\end{array}$ & 3.50 & Agree \\
\hline $\begin{array}{l}\text { 4. The ranking parameters are known } \\
\text { to the community. }\end{array}$ & 3.60 & Agree \\
\hline $\begin{array}{l}\text { 5. The evidences are considered in } \\
\text { ranking the employee. }\end{array}$ & 4.53 & Strongly \\
& Agree \\
\hline $\begin{array}{l}\text { 6. The general policy and guidelines } \\
\text { on ranking is clear. }\end{array}$ & 3.41 & Agree \\
\hline $\begin{array}{l}\text { 7. The procedure for application on } \\
\text { ranking is specified on the manual. }\end{array}$ & 4.17 & Agree \\
\hline \begin{tabular}{c} 
Average Weighted Mean \\
\hline
\end{tabular} & Agree \\
\hline
\end{tabular}

Generally, the average weighted mean of the faculty ranking is 3.86 which is interpreted as agree. This data implies that respondents highly perceived that the school give due attention to the faculty ranking which is clearly known to the community. Moreover, this faculty ranking policies are well-stipulated as a provision in the manual where teachers are well-informed and properly guided about it. Among the indicators, the indicator 5, "the evidences are considered in ranking the employee" got the highest mean of 4.53 which is interpreted as strongly agree. This data tells that respondents are very much agreed that in ranking applications their papers are being scrutinized and thoroughly checked. It also implies that ranking applications is being taken seriously by the administration for this would serve as a basis for the scheming of employee's salary.

However, the indicator 6, "the general policy and guidelines on ranking is clear", got the lowest rating of 3.41 which is interpreted as agree. Even though it is lowest among the indicators but still the respondents agreed that the policy and guidelines in ranking are clear and well-communicated to the teachers. It shows that the administration highly considers that the policies and guidelines should be transparent in the school community for them to work-out professionally in meeting the requirements for faculty ranking.

Other indicators on faculty ranking are; indicator 1 "the educational qualification is the major bases in ranking the faculty" got 4.13 which is rated as agree; indicator 2, "the points given in the ranking parameters are justifiable and reasonable" rated 3.90, agree; indicator 4, "the performance evaluation is included in the ranking parameters" got 3.50, agree; indicator 4, "the ranking parameters are known to the community" got 3.6, agree, indicator 7, "the procedure for application on ranking is specified on the manual" got 4.17 which is interpreted as agree.

\section{Salary and Benefits}

Table 4 shows the results of assessing the existing faculty manual in terms of salary and benefits.

Table 4.Salary and Benefits

\begin{tabular}{|l|c|c|}
\hline INDICATORS & $\begin{array}{c}\text { WEIGHTED } \\
\text { MEAN }\end{array}$ & $\begin{array}{c}\text { INTERPRE } \\
\text { TATION }\end{array}$ \\
\hline $\begin{array}{c}\text { 1. The salary scheme and the fringe } \\
\text { benefits are clearly stipulated in the } \\
\text { manual. }\end{array}$ & 4.40 & $\begin{array}{c}\text { Strongly } \\
\text { Agree }\end{array}$ \\
\hline $\begin{array}{c}\text { 2. The salary scheme is in accordance } \\
\text { with the guidelines and in } \\
\text { qualifications set forth needed for the } \\
\text { position. }\end{array}$ & 4.13 & Agree \\
\hline $\begin{array}{l}\text { 3. The procedures for salary increase and } \\
\text { availment of benefits are clearly } \\
\text { stated in the manual. }\end{array}$ & 3.80 & Agree \\
\hline $\begin{array}{l}\text { 4. There are diversified benefits that can } \\
\text { be availed by faculty. }\end{array}$ & 3.48 & Agree \\
\hline $\begin{array}{c}\text { 5. The salary increase and the availment } \\
\text { benefits are consistently } \\
\text { implemented }\end{array}$ & 3.20 & Neutral \\
\hline Average Weighted Mean & 3.80 & Agree \\
\hline
\end{tabular}

Generally, the assessment of the salary and benefits by the respondents got an average weighted mean of 3.80 which is interpreted as agree. This means that the respondents agreed that manual has the provision in terms of receiving salary and benefits for employees. Moreover, this provision serves as counter checking for employees to receive what they ought and expected for. On the presented indicators, indicator 1, "the salary scheme and the fringe benefits are clearly stipulated in the manual" got the highest rating of 4.40 which is interpreted as strongly agree. Data reveals that the manual had the clear provision on the amount of the salary and benefits that the employees will be receiving.

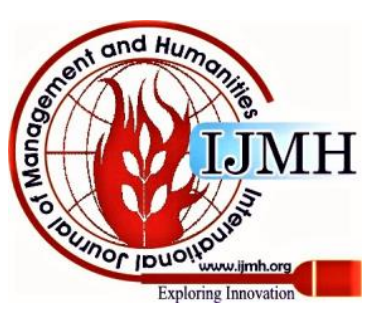


It further shows that this transparency of the salary and benefits makes the employees highly engaged and motivated in dealing with their jobs. On the other hand, indicator 5, "the salary increase and the availment of benefits are consistently implemented" got the lowest rating of 3.20 which is interpreted as neutral.

This data reveals that despite of the clear provision in terms of salary and benefits, the respondents observed that it was not consistently implemented. Meaning there are some instances that salary scheme implementation are not followed or the giving of the benefits are not availed.

Other indicators are rated as follows; indicator 2, "the salary scheme is in accordance with the guidelines and in qualifications set forth needed for the position" rated as 4.13 and interpreted as agree; indicator 3, "the procedures for salary increase and availment of benefits are clearly stated in the manual" got 3.80 rated as gree; and indicator 4, "there are diversified benefits that can be availed by faculty" got a rating 3.48 and is interpreted as agree.

Summary of Weaknesses on the Existing Manual

Table 5 shows the summary of the identified weaknesses of the existing faculty manual.

Table 5. Summary of Weaknesses

\begin{tabular}{|c|c|c|}
\hline AREA & INDICATORS & $\begin{array}{c}\text { WEIGHTED } \\
\text { MEAN }\end{array}$ \\
\hline $\begin{array}{c}\text { Employment } \\
\text { Policies }\end{array}$ & $\begin{array}{c}\text { 5. The implementations of the } \\
\text { employment policies were } \\
\text { consistent in the provision of the } \\
\text { manual. }\end{array}$ & 3.33 \\
\hline $\begin{array}{c}\text { Faculty } \\
\text { Qualifications }\end{array}$ & $\begin{array}{c}\text { 3. The teaching experience is required } \\
\text { for hiring. }\end{array}$ & 3.38 \\
\hline $\begin{array}{c}\text { Salary and } \\
\text { Benefits }\end{array}$ & $\begin{array}{c}\text { 5. The salary increase and the } \\
\text { availment of benefits are } \\
\text { consistently implemented }\end{array}$ & 3.20 \\
\hline
\end{tabular}

The table 5 shows the weaknesses as perceived by the teachers on the existing faculty manual. As shown in the table, the weaknesses are mostly on the manner of implementation but not on the provision stated on the manual. Thus, it can be inferred that respondents agreed that the provision meets their expectations and in accordance with the standard set forth for teaching but there is a need for the management to revisit the consistency of the implementation.

\section{Affective Commitment}

Table 6 shows the level of affective commitment of the respondents as perceived by the respondents as a result of the provision and implementation of the faculty manual.

Table 6. Affective Commitment

\begin{tabular}{|c|c|c|}
\hline INDICATORS & $\begin{array}{l}\text { WEIGHTED } \\
\text { MEAN }\end{array}$ & $\begin{array}{l}\text { INTERPRE } \\
\text { TATION }\end{array}$ \\
\hline $\begin{array}{l}\text { 1. I am proud to tell others that I } \\
\text { am part of this institution. }\end{array}$ & 4.54 & $\begin{array}{l}\text { Strongly } \\
\text { Agree }\end{array}$ \\
\hline $\begin{array}{l}\text { 2. I have a strong affection for } \\
\text { this institution. }\end{array}$ & 4.00 & Agree \\
\hline $\begin{array}{c}\text { 3. I feel like "part of the family" } \\
\text { at my institution. }\end{array}$ & 3.41 & Agree \\
\hline $\begin{array}{l}\text { 4. I would be very happy to } \\
\text { spend the rest of my career } \\
\text { with this institution. }\end{array}$ & 3.65 & Agree \\
\hline Average Weighted Mean & 3.90 & Agree \\
\hline
\end{tabular}

The general weighted mean for affective commitment is 3.90 which is interpreted as agree. The data implies that the respondents agreed that they are affectively committed to stay in the organization as a result of the provision and implementation of the existing manual. It further implies that the respondents have the strong intention to stay with the school because they love staying too and not because they are obligated too.

Among the indicators identified, indicator 1 "I am proud to tell others that I am a part of this institution" got the highest weighted mean of 4.54 and is interpreted as strongly agree. This data reveals that the respondents are very happy that they are working in the institution. They are very proud employees of the school. Moreover, they love working in the institution and willing to tell others about it. By that, they are staying affectively in the organization.

On the other hand, the indicator 3, "I feel like part of the family at my institution" got the lowest rating of 3.41 which is interpreted as agree. Though lowest but respondents still agreed that they are treated like a family in the institution. As family they feel valued and cared of. Thus, they are

Other indicators are rated as follows; indicator 2, "I have a strong affection for this institution" got a rating of 4.00 which is interpreted as agree; and indicator 4, "I would be very happy to spend the rest of my career with this institution" got a rating of 3.65 and rated as agree.

Table 7 shows the indicators for job satisfaction as a result of the provision and implementation of the faculty manual.

Table 7. Job Satisfaction

\begin{tabular}{|c|c|c|}
\hline INDICATORS & $\begin{array}{l}\text { WEIGHTED } \\
\text { MEAN }\end{array}$ & $\begin{array}{l}\text { INTERPRE } \\
\text { TATION }\end{array}$ \\
\hline $\begin{array}{l}\text { 1. I like the way the school } \\
\text { handles its personnel. }\end{array}$ & 4.19 & Agree \\
\hline $\begin{array}{l}\text { 2. The like the way the school } \\
\text { policies are put into practice. }\end{array}$ & 4.12 & Agree \\
\hline $\begin{array}{l}\text { 3. I am happy with my pay and } \\
\text { the workloads that I have. }\end{array}$ & 3.54 & Agree \\
\hline 4. I like the working conditions. & 3.56 & Agree \\
\hline $\begin{array}{l}\text { 5. I like the chances for } \\
\text { advancement in my job. }\end{array}$ & 3.51 & Agree \\
\hline $\begin{array}{l}\text { 6. I like the way my job provides } \\
\text { for steady employment. }\end{array}$ & 3.56 & Agree \\
\hline $\begin{array}{l}\text { 7. I have a feeling of } \\
\text { accomplishment I get from } \\
\text { the job. }\end{array}$ & 4.67 & $\begin{array}{l}\text { Strongly } \\
\text { Agree }\end{array}$ \\
\hline Average Weighted Mean & 3.87 & Agree \\
\hline
\end{tabular}

The average weighted mean of job satisfaction is 3.87 which is interpreted as agree. This data implies that respondents agreed that they are satisfied working with the institution because they feel self-efficacy and organizational support.

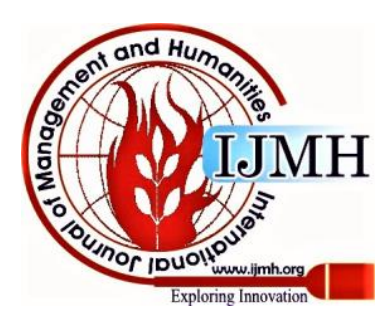


This satisfaction is directly attributable with the clear provision and implementation of the existing faculty manual.

On the presented indicators, indicator 7, "I have a feeling of accomplishment I get from the job" got the highest weighted mean of 4.67 which is interpreted as strongly agree. This data shows that respondents agreed that they are satisfied with their job because of the sense of accomplishment that they feel while working in the organization. The results further claim that this employee feeling of accomplishment is the results of the properly implemented provisions of the faculty manual.

However, indicator 5, "I like the chances for advancement in my job" got the lowest rating of 3.51 and is interpreted as agree. Although some do not agree but it can be infer that majority are able to specify that they like advancement in terms of job in the organization. They believe that there is advancement or promotion if they were able to meet the qualifications needed on the provision of the manual.

Other indicators had the following ratings; indicator 1 , "I like the way the school handles its personnel" got 4.19 rated as agree; indicator 2, "I like the way the school policies are put into practice" got 4.12 which is interpreted as agree; indicator 3, "I am happy with my pay and the workloads that I have" got a rating of 3.54 and interpreted as agree; indicator 4, "I like the working conditions" got a rating of 3.56 rated as agree; and, indicator 6, "I like the way my job provides for steady employment" rated at 3.56 which is interpreted as agree.

Significant Relationship of the Provision and Implementation of faculty manual to Affective Commitment

Table 8 shows the significant relationship of the provision and implementation of the existing faculty manual to Affective Commitment.

Table 8. Significant Relationship of the Provision and Implementation to Affective Commitment

\begin{tabular}{|c|c|c|c|c|c|}
\hline $\begin{array}{c}\text { Variables of } \\
\text { the study }\end{array}$ & Mean & $\mathrm{R}$ & $\mathrm{p}$ & $\begin{array}{c}\text { Decisio } \\
\mathrm{n}\end{array}$ & $\begin{array}{c}\text { Informatio } \\
\mathrm{n}\end{array}$ \\
\hline $\begin{array}{c}\text { Provision and } \\
\text { Implementatio } \\
\mathrm{n}\end{array}$ & 3.84 & 0.82 & $\begin{array}{c}0.000 \\
1\end{array}$ & reject & $\begin{array}{c}\text { There is a } \\
\text { high } \\
\text { positive } \\
\text { correlation }\end{array}$ \\
\hline $\begin{array}{c}\text { Affective } \\
\text { Commitment }\end{array}$ & 3.90 & & & & \\
\hline
\end{tabular}

Table 8 shows that there is a positive correlation between the provision and implementation, and affective commitment. Meaning, the more the provision of the manual is implemented, the more the respondents are affectively committed to stay in the organization. But, if the manual is not-well implemented, the employees also are not that affectively committed. Therefore, the null hypothesis that says there is no significant relationship with the provision and implementation of the faculty manual and the affective commitment is rejected.

\section{Significant Relationship of the Provision and Implementation to Job Satisfaction}

Retrieval Number:100.1/ijmh.L10860841220

DOI:10.35940/ijmh.L1086.0841220

Journal Website: www.ijmh.org
Table 9 shows the significant relationship of the provision and implementation of the existing faculty manual to the job satisfaction.

Table 9. Significant Relationship of the Provision and Implementation to Job Satisfaction

\begin{tabular}{|c|c|c|c|c|c|}
\hline $\begin{array}{c}\text { Variables of the } \\
\text { study }\end{array}$ & Mean & $\mathrm{R}$ & $\mathrm{p}$ & Decision & Information \\
\hline $\begin{array}{c}\text { Provision and } \\
\text { Implementation }\end{array}$ & 3.84 & 0.75 & 0.000 & reject & $\begin{array}{c}\text { There is high } \\
\text { positive } \\
\text { correlation }\end{array}$ \\
\hline Job Satisfaction & 3.87 & 9 & 1 & & \\
\hline
\end{tabular}

Table 9 reveals that there is a positive correlation between provision and implementation to the job satisfaction of the respondents. It implies that there is a direct relationship among variables, thus, if the provision of the manual is well-implemented it resulted to higher job satisfaction among employees. Meanwhile, if the provision of the manual is not that followed it causes dissatisfaction among employees. Therefore, the null hypothesis that tells that there is no significant relationship between provision and implementation, and job satisfaction is rejected.

\section{CONCLUSIONS}

Regarding the results of the study, it can be concluded that there is a high positive correlation between the provision and implementation of faculty manual and teachers' affective commitment. Therefore, the null hypothesis (Ho1) which states that there is no significant relationship between the provision and implementation of faculty manual and teachers' affective commitment is rejected. Moreover, there is a high positive correlation between the provision and implementation of faculty manual and teachers' job satisfaction. Therefore, the null hypothesis (Ho2) which states that there is no significant relationship between the provision and implementation of faculty manual and teachers' job satisfaction is rejected. The study further concluded that the RMMC faculty manual had all the necessary provisions in terms of employment policies, faculty qualifications, faculty ranking, and salary and benefits but it needs thorough implementation by the administration to make employees highly committed and highly satisfied in the organization.

\section{RECOMMENDATIONS}

The study recommends that existing faculty manual of RMMC must be revisited and reexamined by the administration and give emphasis on the manner of its implementation. The results of the evaluation of the administration must be carefully studied and compared with the results coming from the respondents. By doing so, they can come up with the ideas regarding the factors that must be included in the revised faculty manual of RMMC. 
Thus, the results of this study can be used as a baseline that can be adapted for improvement.

\section{ACKNOWLEDGMENT}

The author highly commends the support of the administration of Ramon Magsaysay Memorial Colleges (RMMC) in the conduct of the study. The author also acknowledges the faculty members in answering the survey questionnaires.

\section{REFERENCES}

1. Allison, M. \& Kaye, J. (2011). Strategic Planning for Nonprofit Organizations: A Practical Guide and Workbook, John Wiley \& Sons: Hoboken, NJ

2. Al-dalahmeh, M., Masa'deh, R., Khalaf,R.K.A., Obeidat, B.Y. (2018) The Effect of Employee Engagement on Organizational Performance Via the Mediating Role of Job Satisfaction: The Case of IT Employees in Jordanian Banking Sector. Modern Applied Science. 12. 17. 10.5539/mas.v12n6p17.

3. Armstrong, M. (2006). A Handbook of Human Resource Management Practice, Tenth Edition,Kogan Page: London.

4. Arora, N., Nuseir, M. T., Nusair, T. T., \& Arora, R. (2012). Study-based Moderators Influencing the Relationship Between Organizational Climate and Employee's Organization Commitment. EuroMed Journal of Business, 7, 201-220. doi:10.1108/14502191211245615

5. Balassiano, M., \& Salles, D. (2012). Perceptions of Equity and Justice and Their Implications on Affective Organizational Commitment: A Confirmatory Study in a Teaching and Research Institute. Brazilian Administration Review, 9, 268-286. Retrieved from http://anpad.org.br/periodicos/content/frame_base.php?revista=2

6. Barkley, E.F. \& Major, C.H. (2020). Student Engagement Techniques: A Handbook for College Faculty, Jon Wiley \& Sons: Hoboken, N.J.

7. Darling-Hammond, D. \& McLaughlin, M.W. (1995). Policies that Support Professional Development in an Era of Reform, Phi Delta Kappan, 76(8) pp 597-604

8. Eaton, S.C. (2003). If You Can Use Them: Flexibility Policies, Organizational Commitment, and Perceived Performance, Retrieved from

https://onlinelibrary.wiley.com/doi/abs/10.1111/1468-232X.00285

9. Edgar, F. \& Geare, A. (2005). HRM practice and employee attitudes: different measures - different results, Personnel Review, Vol. 34 No. 5 , pp. 534-549

10. Ellenbecker, C. H., \& Cushman, M. (2012). Home Healthcare Nurse Retention and Patient Outcome Model: Discussion and Model development. Journal of Advanced Nursing, 68, 1881-1893. doi:10.1111/j.1365-2648.2011.05889.x

11. Ellickson, M.C., \& Logsdon, K. (2002). Determinants of Job Satisfaction of Municipal Government Employees .Public Personnel Management, Vol. 31 (3), 343-358.

12. Juevesa, R.D., Juevesa, C.V., \& Castino, J.M.P (2020). Employee Engagement, Commitment, Satisfaction and Organizational Performance among Multigenerational Workforce, International Journal of Research in Engineering, Science and Management, Vol. 3 No. 7, pp. 36-40.

13. Jussila, I., Byrne, N., \& Tuominen, H. (2012). Affective Commitment in Co-operative Organizations: What makes members want to stay? International Business Research, 5(10), 1-10. doi:10.5539/ibr.v5n10p1

14. Kimura, T. (2013). The Moderating Effects of Political Skill and Leader-Member Exchange on the Relationship Between Organizational Politics and Affective Commitment. Journal of Business Ethics, 116, 587-599. doi:10.1007/s10551-0121497-x

15. Koziel, D.L. (2009). A Needs Analysis for Northcentral Technical College Dental Hygienist Program Faculty Manual, Retrieved from https://minds.wisconsin.edu/bitstream/handle/1793/43193/2009Koziel d.pdf?sequence $=1$

16. Lettner-Rust, H. (2018). Revising the Faculty Manual: The Clien Project in Your Backyard. Prompt: A Journal of Academic Writing Assignments, 2(2). https://doi.org/10.31719/pjaw.v2i2.25

17. Leroy, H., Palanski, M., \& Simons, T. (2012). Authentic Leadership and Behavioral Integrity as Drivers of Follower Commitment and Performance. Journal of Business Ethics, 107, 255-264. doi:10.1007/s10551-011-1036-1

18. Lindsey,R. B, Nuri-Robins, K., Terrell, R.D. \& Lindsey, T.D. (2018) Cultural Proficiency: A Manual for School Leaders, Sage Publication, Ltd: Thousand, Oaks, CA
19. Meyer, J.P, \& Allen, N.J (1997). Commitment in the Workplace. Sage Publication: Thousand Oaks, CA

20. Mital, A., Nicholson, A.S., \& Ayuob, M.M. (1997). A Guide to a Manual Materials Handling, Athenaeum Press Ltd: Bristol,PA

21. Payne, G. \& Majale,M. (2004). The Urban Housing Manual, Cromwell Press Limited: Sterling, VA.

22. Pierangeli, L. (2006). Developing a Clinical Teaching Handbook and Reference Manual for Part-time Clinical Faculty, NURSE EDUCATOR: July-August 2006 - Volume 31 - Issue 4 - p 183-185

23. Raziq, A., Ilyas, R. \& Talpur, M. (2019). An Exploration of Job Satisfaction Indices for Teachers in Balochistan, Pakistan. 10 10.14456/ITJEMAST.2019.180.

24. Sani, A. (2013). Role of Procedural Justice, Organizational Commitment and Job Satisfaction on Job Performance: The Mediating Effects of Organizational Citizenship Behavior. International Journal of Business \& Management, 8, 57-67. doi:10.5539/ijbm.v8n15p57

25. Spector, P. E. (1997). Job Satisfaction: Application, Assessment, Causes, and Consequences. Sage Publication: Thousand Oaks, CA

26. Statt, D. (2004). The Routledge Dictionary of Business Management, Third Edition, Routledge Publishing, Detroit, p. 78

27. Steinert, Y., Mann K., Centeno A., Dolmans, D., Spencer, J., Gelula, M. \& Prideaux, D. (2006). A systematic review of faculty development initiatives designed to improve teaching effectiveness in medical education: BEME Guide No. 8, Medical Teacher, 28:6, 497-526, DOI: $10.1080 / 01421590600902976$

\section{AUTHOR PROFILE}

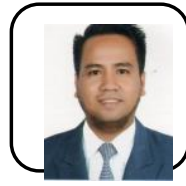

Roel D. Juevesa, is a Certified Public Accountant (CPA) and a Doctor in Management specializing in Human Resource Management (DM-HRM). Currently, he is employed as a Human Resource Director and a Business College Faculty at Ramon Magsaysay Memorial Colleges (RMMC), General Santos City, Philippines. He is also a Graduate School Professor at Notre Dame of Dadiangas University (NDDU), General Santos City, Philippines. His researches focus on accounting and financial management, business management, and educational management.
Published By:

Blue Eyes Intelligence Engineering \& Sciences Publication (C) Copyright: All rights reserved.

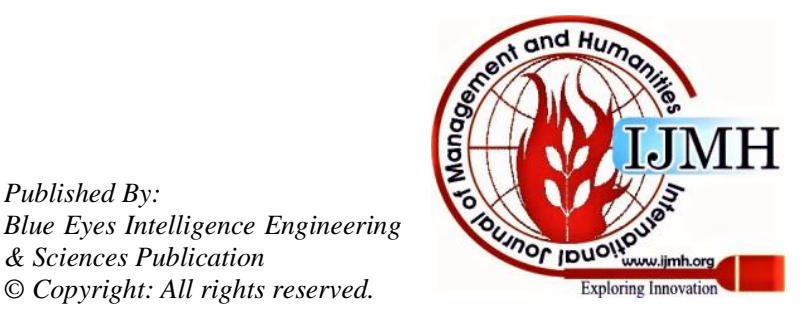

